\title{
Biofiltration for ammonia removal from composting exhaust gases
}

Estel·la Pagans, Xavier Font, Antoni Sánchez*

Escola Universitària Politècnica del Medi Ambient

Universitat Autònoma de Barcelona

Rbla Pompeu Fabra 1, 08100-Mollet del Vallès (Barcelona, Spain)

*Corresponding Author: Dr. Antoni Sánchez

Escola Universitària Politècnica del Medi Ambient

Universitat Autònoma de Barcelona

Rbla Pompeu Fabra 1, 08100-Mollet del Vallès (Barcelona, Spain)

Tel.: (34) 9357967 84; Fax: (34) 935796785

E-mail: asanchez@eupma.uab.es 


\begin{abstract}
A study was conducted to investigate the utilization of mature compost as a biofilter media for the removal of ammonia from the exhaust gases of the composting process. Source-selected organic fraction of municipal solid wastes, digested wastewater sludge and animal by-products were composted in a pilot-scale reactor and the exhaust gas was treated in a biofilter. Due to the high ammonia adsorption and absorption capacity of the compost media, no delay or start-up phase was observed and high removal efficiencies were achieved from the beginning of the experiments. A global ammonia removal efficiency of $95.9 \%$ was obtained in the biofilter for a loading rate range of 846-67100 $\mathrm{mg} \mathrm{NH} \cdot \mathrm{m}^{-3}$ biofilter $\cdot \mathrm{h}^{-1}$. However, an important reduction of ammonia removal was observed when the waste gas contained high $\mathrm{NH}_{3}$ concentration (more than $2000 \mathrm{mg} \mathrm{NH} \cdot \mathrm{m}^{-3}$ ), which corresponded with the case of animal by-products composting.
\end{abstract}

Keywords: Ammonia removal, Biofiltration, Compost media, Composting, Organic solid wastes. 


\section{Introduction}

At present, solid waste management is becoming a global problem in developed countries. Composting is an environmentally friendly technology to treat and recycle organic wastes. Composting is not only used for the organic fraction of municipal solid wastes, but is also applied to residuals coming from industrial activities. Municipal or industrial wastewater sludge [1] and animal by-products [2] are examples of organic solid wastes susceptible to composting.

At present, odor emissions and atmospheric pollution are the most common problems associated with composting of organic wastes in large-scale facilities. Composting installations present numerous odor sources, including the reception and handling of materials, active composting, stock piling, etc. Exhaust gases from composting are usually characterized by high flow rates and low pollutant concentrations. Ammonia has received much attention as it can be easily identified from other composting odors, often represents the main nitrogen gas emitted during composting and it can be released in large amounts. Degradation of protein, urea or uric acid produces ammonium [3]. In this process, $\mathrm{pH}$, temperature and moisture content determine the $\mathrm{NH}_{3} / \mathrm{NH}_{4}{ }^{+}$balance and hence the ammonia emission. Nitrogen losses from composting material normally imply a poor agronomical quality of the final compost and environmental pollution problems, such as odor nuisance and acid rain [4]. Ammonia emissions in a composting process of organic fraction of municipal solid wastes varies between 18 to $150 \mathrm{~g} \mathrm{NH}_{3} \cdot \mathrm{Mg}^{-1}$ waste [5], while ammonia concentrations up to $700 \mathrm{mg} \mathrm{NH} \mathrm{NH}_{3} \cdot \mathrm{m}^{-3}$ have been reported in exhaust gases from sludge composting [6].

Among the available technologies for gas treatment, biofiltration is an odor reduction technique that can be adapted to reduce emissions from composting processes 
[7]. It is considered a suitable technology in terms of waste recycling, emissions reduction, and low construction and operating costs [8]. In a biofilter, a contaminated/odorous gas stream passes through a biologically enriched layer of a filter material such as soil, wood chips, compost or mixed materials, followed by biodegradation of the absorbed/adsorbed pollutant. The byproducts of microbial oxidation are primarily water, carbon dioxide, mineral salts, some volatile organic compounds and microbial biomass [9].

Several important variables affect the performance of a biofilter. Microbial activity is affected by moisture content, $\mathrm{pH}$, nutrient limitation, temperature and microbiology of the biofilter medium. Compost-based media have been used extensively in recent years because they have complex microbial communities capable of degrading several pollutants, and they have good water retention properties and a suitable organic matter content. Mature compost media are inexpensive and readily available; therefore their use in biofilters is a good option in composting facilities. Additional nutrients are not usually required for biofilters based on compost because it has significant amounts of organic nitrogen and other micronutrients. At the same time, the high ammonia content in most composting gases supplies enough nitrogen for biofilters used on composting plants [6]. Compost can be mixed with bulking agents to avoid high pressure drop, clogging and flow channelling and to increase its durability $[9,10]$.

Biofilters permit a high removal of ammonia, usually around $95-98 \%$ on a wide variety of support materials, either organic or inorganic [11]. Liang et al. (2000) investigated the long-term ammonia removal using a compost biofilter and achieving removal efficiencies above $95 \%$ with loads ranging from 0.33 to $16.25 \mathrm{mg} \mathrm{NH}_{3} \cdot \mathrm{kg}$ 
$\operatorname{media}^{-1} \cdot \mathrm{h}^{-1}$ and empty bed retention time (EBRT) ranging from 31.8 to $78 \mathrm{~s}$ [10]. Other studies on biofiltration of exhaust gases in composting facilities indicate reductions of $98 \%$ for an average loading rate of $10180 \mathrm{mg} \mathrm{NH}{ }_{3} \cdot \mathrm{m}^{-3}$ biofilter $\cdot \mathrm{h}^{-1}$ and an EBRT of $16 \mathrm{~s}$ $[12,13]$. There is, however, a lack of knowledge about the operational limits of biofiltration when treating odorous waste gases containing high ammonia concentrations [14], such as some of the composted materials in Spain.

This work studies the efficiency of a compost biofilter for the removal of ammonia from the exhaust gases of the composting process of source-selected organic fraction of municipal solid wastes (OFMSW), digested wastewater sludge (DS) and animal by-products (AP).

\section{Materials and Methods}

\subsection{Organic wastes composted}

OFMSW was obtained from the municipal composting plant of Jorba (Barcelona, Spain); DS was obtained from the urban wastewater treatment plant of La Llagosta (Barcelona, Spain); and AP, consisting of rejected parts of chicken and rabbit (viscera, carcasses, feathers, etc.), were obtained from the municipal composting plant of Jorba (Barcelona, Spain). All wastes were manually mixed with bulking agents (chopped pruning waste) to ensure an optimal porosity and moisture content. In the case of OFMSW two volumetric ratios of bulking agent:waste $(5: 1,1: 1)$ were tested.

\subsection{Experimental set-up}

OFMSW, DS and AP were composted in a thermally insulated $30-\mathrm{dm}^{3}$ laboratory reactor. Air was supplied to the reactor intermittently by a suction-type 
blower (Sensotran, Spain, model GCYA/BA) to control the content of oxygen (Sensotran, Spain, model Sensox 6C) in the composting material to ensure aerobic conditions (oxygen concentration above $10 \%)$. The blower extracted the air $\left(5 \mathrm{dm}^{3} \cdot \mathrm{min}^{-}\right.$

$\left.{ }^{1}\right)$ through the compost mass and discharged the exhaust gas to a pilot-scale biofilter filled with mature compost as a biofilter medium. Down-flow direction was selected to improve moisture control. Since temperature of off-gases from the composting reactor was below $35^{\circ} \mathrm{C}$, it was not necessary to cool down the gas entering the biofilter and it operated within a mesophilic temperature range throughout the whole experimental period. A scheme of the composting and biofiltration system is shown in Figure 1.

The biofilter was constructed with circular methacrylate pipe, and its dimensions were: height $1.2 \mathrm{~m}$ and diameter $0.2 \mathrm{~m}$. The media depth was $0.23 \mathrm{~m}$, resulting in a total bed volume of $7.2 \mathrm{dm}^{3}$, a volumetric loading rate of $0.69 \mathrm{dm}^{3} \cdot \mathrm{dm}^{-3}$ media $\cdot \mathrm{min}^{-1}$ and a gas retention time of $86 \mathrm{~s}$. Initial properties of the mature compost used as the biofilter media are shown in Table 1.

Two runs were conducted for each waste composted, and each run lasted about 1 week. Experiments were carried out continuously for about 2 months. This paper only presents the results of the most significant tests, one for each waste. Differences of ammonia emissions, temperature profiles and ammonia biofiltration among replicate composting experiments were in the range of $10-20 \%$.

\subsection{Analytical methods}

Ammonia concentrations of the exhaust gas from the composting reactor and the biofiltration process were measured online by an electrochemical gas sensor (Bionics Instrument Co, Tokyo, Japan). Temperatures of the composting materials were 
monitored during the composting period with a Pt100 probe (Desin, Spain, model SR$\mathrm{NOH})$. All the values were displayed and recorded with a personal computer every 30 minutes using a commercial data logger (Desin, Spain, DAS-8000). Values of elimination capacity and removal efficiency are presented as an average of 6 values obtained during a period of 3 hours.

Periodic measures of the temperature and pressure drop across the media were carried out manually using a digital thermometer (Hanna, mod. Checktemp) and a Utype water manometer.

Physico-chemical properties of the biofilter compost media were analyzed before and after the biofiltration process for determining moisture content (MC) on a wet basis, organic matter content (OM), respirometric index (RI), organic nitrogen and $\mathrm{NH}_{4}{ }^{+}-\mathrm{N}$ content, carbon/nitrogen ratio $(\mathrm{C} / \mathrm{N}), \mathrm{pH}$ and electrical conductivity. These parameters were analyzed according to accepted methods [15].

\section{Results and Discussion}

Properties of the compost material before and after 2 months of biofilter operation are shown in Table 1 . The MC increased from initial value of $40.4 \%$ to final value of $60.8 \%$ due to the absorption of moisture from the exhaust gas. It is reported that exhaust gases from composting are usually water-saturated [6]. The value of $\mathrm{pH}$ and electrical conductivity did not change significantly. While some authors [16] have reported that compost biofiltration of ammonia resulted in the acidification of the support material, it was found by others [14] that about $50 \%$ of the ammonia was nitrified and the other $50 \%$ remained in the filter medium as ammonium. In our case, the $\mathrm{NH}_{4}{ }^{+}-\mathrm{N}$ concentration increased as the compost media absorbed ammonia and the 
organic nitrogen slightly decreased. Similar results were obtained by Liang et al. (2000) [10]. The biofilter media's $\mathrm{C} / \mathrm{N}$ ratio decreased as the effluent gas from composting reactor was biofiltered. Biological activity (measured as RI) increased throughout the biofiltration process demonstrating the growth of an active biomass during the experiments. The increase in the RI value can be due to either a reactivation of biological activity of the compost media itself or to the formation of new active biological colonies resulting from the biofiltration process.

The biofilter operated in the mesophilic range (temperature between 15 and $\left.26^{\circ} \mathrm{C}\right)$. Although temperature in the biofilter was affected by ambient temperature, the values were in the optimum range reported for ammonia removal within 15 and $35^{\circ} \mathrm{C}$ $[6]$.

The pressure drop exhibited an increase of $17 \mathrm{~mm}$ water due to the gradual clogging and compaction of the compost particles. This fact was more evident when the loading rate and the moisture content of the packing material increased. However, the value of the pressure drop did not increase to a critical value during the whole period of the experiment and no channelling phenomena were observed.

Temperature profiles of the compost reactor for each experiment are presented in Figures 2, 3, 4 and 5. Temperature is routinely used as an indicator of the biological activity of the composting process. Optimum decomposition takes place in the range of $45-55^{\circ} \mathrm{C}$ and pathogen inactivation in the compost is favorable over $55^{\circ} \mathrm{C}$. The temperature of the three wastes reached the thermophilic range, which corresponds to a peak of degradation of fresh organic matter, within one to two days. The maximum temperatures achieved for OFMSW (5:1), OFMSW (1:1), DS and AP were $52.0^{\circ} \mathrm{C}$, $58.0^{\circ} \mathrm{C}, 61.2^{\circ} \mathrm{C}$ and $66.2^{\circ} \mathrm{C}$ respectively. 
Figures 2, 3, 4 and 5 also show the variation of ammonia concentration in the inlet and outlet gas stream of the biofilter and the resulting removal efficiencies for the four composted wastes. The ammonia inlet concentration ranges from 16 to $36 \mathrm{mg}$ $\mathrm{NH}_{3} \cdot \mathrm{m}^{-3}$ for OFMSW (5:1), from 5 to $530 \mathrm{mg} \mathrm{NH} \cdot \mathrm{m}^{-3}$ for OFMSW (1:1), from 10 to $650 \mathrm{mg} \mathrm{NH} \cdot \mathrm{m}^{-3}$ for DS, and from 60 to $3150 \mathrm{mg} \mathrm{NH} \cdot \mathrm{m}^{-3}$ for AP. The highest ammonia emissions were observed during composting of AP due to their high initial nitrogen content $(4.3 \%$ in comparison to those found in OFMSW and DS, which were $2.2 \%$ and $2.6 \%$ respectively), especially proteins that are easily biodegradable. The low ammonia losses obtained during composting of OFMSW (5:1) could be related to the high $\mathrm{C} / \mathrm{N}$ ratio of the mixture, which is one of the main factors controlling $\mathrm{NH}_{4}{ }^{+}$ availability of the raw composting material [17].

The exhaust gas from the biofilter ranges from 0 to $1 \mathrm{mg} \mathrm{NH} \cdot \mathrm{m}^{-3}$ for OFMSW (5:1), from 0 to $39 \mathrm{mg} \mathrm{NH} \cdot \mathrm{m}^{-3}$ for $\operatorname{OFMSW~(1:1),~from~} 0$ to $17 \mathrm{mg} \mathrm{NH} \cdot \mathrm{m}^{-3}$ for $\mathrm{DS}$, and from 30 to $590 \mathrm{mg} \mathrm{NH} \cdot \mathrm{m}^{-3}$ for $\mathrm{AP}$. The comparison of cumulative ammonia emissions before and after biofiltration for the four composted wastes is shown in Table 2.

The highest value of ammonia concentration in the inlet gas stream corresponded with high values of composting temperature, showing an intimate relationship between the composting temperature and the ammonia emissions. Several studies, such as composting of deep litter [18] and composting of poultry manure [3], show that the highest peak of ammonia emission occurs during the temperature increase period. According to Sikora (1999), $\mathrm{NH}_{3}$ solubility is reduced by $30 \%$ when temperature increases from 40 to $55^{\circ} \mathrm{C}$ and when $\mathrm{pH}$ increases [19], which causes the increase of ammonia in the exhaust gas of the composting process. 
Due to the high ammonia adsorption and absorption capacity of the compost media, no start-up period was observed for the removal of ammonia (Figures 2, 3 and 4, Table 2). New biofilter material often provides good treatment for the first few days of operation because it acts as an adsorber [20]. Therefore, a global removal efficiency of $98.8 \%$ was obtained at a global loading rate of $846 \mathrm{mg} \mathrm{NH} \cdot \mathrm{m}^{-3}$ biofilter $\cdot \mathrm{h}^{-1}$ (day 0-5 for OFMSW (5:1)), a global removal efficiency of $95.9 \%$ was obtained at a global loading rate of $7500 \mathrm{mg} \mathrm{NH} \cdot \mathrm{m}^{-3}$ biofilter $\mathrm{h}^{-1}$ (day 0-6 for OFMSW (1:1)) and a global removal efficiency of $99.4 \%$ was obtained at a global loading rate of $6670 \mathrm{mg} \mathrm{NH} \mathrm{NH}_{3} \cdot \mathrm{m}^{-3}$ biofilter $\cdot \mathrm{h}^{-1}$ (day 0-6 for DS). Even increasing the global loading rate to $67100 \mathrm{mg}$ $\mathrm{NH}_{3} \cdot \mathrm{m}^{-3}$ biofilter $\cdot \mathrm{h}^{-1}$ (day 0-4 for AP), the removal efficiency only slightly decreased to a global value of $89.5 \%$. However, for AP from day 4 on, the removal efficiency in the biofilter strongly dropped to an average value of $46.7 \%$ (ranging from $90 \%$ at the beginning of this period to some values well below $30 \%$ at the end of this period). This phenomenon may be explained by two possible causes: 1) the compost biofilter might have reached its maximum ammonia adsorption and absorption capacity i.e., during this period, as adsorption and absorption capacities are probably saturated, ammonia removal may only be possible by biological degradation. However, in this case it would be expected a more sudden rise in the ammonia concentration in the exhaust gas from the biofilter; 2) therefore, it is more probable that microbial activity was inhibited by waste gases containing high ammonia concentrations $\left(>2000 \mathrm{mg} \cdot \mathrm{m}^{-3}\right)$. According to Hartikainen et al. (1996) toxification of the biofilter can cause a drop in the removal efficiency for ammonia at a waste gas concentration level exceeding $45-50 \mathrm{mg} \mathrm{NH} \cdot \mathrm{m}^{-3}$ [21]. On the contrary, Smet et al. (2000) reported no toxicity effect of ammonia on the nitrifying activity of the biofilter even at ammonia concentrations up to $550 \mathrm{mg} \mathrm{NH} \cdot \mathrm{m}^{-}$ 
${ }^{3}$ [14]. However, a recent study on the modelization of ammonia biofiltration, has reported that high concentrations of free ammonia in the support material can strongly inhibit the biological activity of a biofilter [22]. This fact can explain the observed low elimination capacities at low loading rates (Figure 6). Nevertheless, a combination of the two causes considered, jointly with other phenomenon such as mass transfer limitation [23], can be responsible for the drop observed in the ammonia removal efficiency.

No significant leachate production in the biofilter was observed in the case of OFMSW or DS, as expected, since no water and nutrients additions were carried out. Only in the case of AP $1.9 \mathrm{dm}^{3}$ of leachate were collected, which was probably due to the high temperature achieved in the composting process, which favoured water evaporation and transport to the biofilter media where it condensed. The characteristics of this leachate were only determined once, resulting in: $\mathrm{pH} 8.46$, electrical conductivity $26.6 \mathrm{mS} \cdot \mathrm{cm}^{-1}$ and $\mathrm{NH}_{4}{ }^{+}-\mathrm{N}$ concentration $8.5 \mathrm{~g} \cdot \mathrm{dm}^{-3}$. Assuming these values, the maximum nitrogen concentration in the leachate would represent $20 \%$ of the total ammonia load to the biofilter.

The dependence of ammonia removal rate on loading rate is shown in Figure 6. The maximum ammonia elimination capacity of the biofilter was $85200 \mathrm{mg} \mathrm{NH} \mathrm{NH}_{3} \cdot \mathrm{m}^{-3}$ biofilter $\cdot \mathrm{h}^{-1}$ at a loading of $96800 \mathrm{mg} \mathrm{NH} \cdot \mathrm{m}^{-3}$ biofilter $\cdot \mathrm{h}^{-1}$. The critical load was 27000 $\mathrm{mg} \mathrm{NH} \cdot \mathrm{m}^{-3}$ biofilter $\cdot \mathrm{h}^{-1}$. From this value there is a drop of the ammonia removal efficiency and the trend line of observation points flattens, relative to the diagonal, which is typical behaviour of biofilters when operating above critical load conditions [20]. However, when the system became saturated or biological activity was inhibited, (day 4-9 for AP), it was not capable of eliminating influent loads lower than the 
estimated critical load. This fact should be taken into account in the design of biofilters treating high ammonia loading rates, especially in composting plants, where operational conditions and wastes composted can be variable.

\section{Conclusions}

Several conclusions can be obtained from this study:

1) Biofiltration technology using compost as biofilter media can effectively remove most of the ammonia content from the composting process of source-selected organic fraction of municipal solid wastes and digested wastewater sludge, achieving removal efficiencies over $95 \%$.

2) The maximum levels of ammonia in exhaust gases corresponded to periods when the highest temperatures were achieved in the composting process, which are usually within the thermophilic range.

3) No start-up phase in the biofilter was observed for the removal of ammonia probably due to the high ammonia adsorption and absorption capacity of the compost media.

4) In the case of animal by-products, only a partial removal of ammonia was obtained due to the high ammonia emissions. This is an important observation with regard to the biofiltration of composting gases with high ammonia concentrations.

5) After achieving a high inlet concentration and cumulative loading of the biofilter, performance declined. The exact cause of the decline was not determined. It could simply be a result of exceedance of the adsorption and absorption capacity of the biofilter, or build-up of by-products that ultimately inhibited biological activity. This is of especial importance in composting plants, where the operational conditions (for instance, bulking agents used, volumetric ratio of bulking agent) or the wastes 
composted can be variable. Further research is necessary in the field of biological treatment of highly polluted ammonia gas streams to determine the exact conditions for the inhibition of the ammonia biofiltration using complex support materials such as compost and treating real exhaust gases.

6) The optimization of the initial composting mixtures is also a key factor in the conservation of nitrogen in compost. This will permit to reduce ammonia emissions to be treated in the biofiltration process.

\section{Acknowledgements}

Financial support was provided by the Spanish Ministerio de Ciencia y Tecnología (Project REN2003-00823). 


\section{References}

1. T. Gea, R. Barrena, A. Artola, A. Sánchez, Monitoring the Biological Activity of the Composting Process: Oxygen Uptake Rate (OUR), Respirometric Index (RI), and Respiratory Quotient (RQ), Biotechnol. Bioeng. 88 (2004) 520-527.

2. European Compost Network, Memorandum including the key messages following the ABP workshop in Maastricht, in: ECN (Eds.), Proceedings of The Animal By-Products Regulation ABP - Impacts and Needs for Composting and Biogas Plants in Europe, Maastricht, 9-10 October 2003.

3. R.C. Hansen, H.M. Keener, W.A. Dick, C. Marugg, H.A.J. Hoitink, Poultry manure composting. Ammonia capture and aeration control, in: ASAE (Eds.), Proceedings of American Society of Agricultural Engineers Meeting, Ohio, 2427 June 1990, paper No. 904062.

4. E. Buijsman, H.F.M. Maas, W.A.H. Asman, Anthropogenic $\mathrm{NH}_{3}$ emissions in Europe, Atmos. Environ. 21 (1987) 1009-1022.

5. J. Clemens, C. Cuhls, Greenhouse gas emissions from mechanical and biological waste treatment of municipal waste, Environ. Technol. 24 (2003) 745-754.

6. R.T. Haug, The Practical Handbook of Compost Engineering, Lewis Publishers, Boca Raton, FL, 1993.

7. J.H. Hong, K.J. Park, Wood chip biofilter performance of ammonia gas from composting manure, Compost Sci. Util. 12 (2004) 25-30.

8. M.E. Lang, R.A. Lager, Odor control for municipal sludge composting, Biocycle 33 (1992) 76-85.

9. R.E. Nicolai, K.A. Janni, Biofilter media mixture ratio of wood chips and compost treating swine odors, Water Sci. Technol. 44 (2001) 261-267. 
10. Y. Liang, X. Quan, J. Chen, J.S. Chung, J.Y. Sung, S. Chen, D. Xue, Y. Zhao, Long-term results of ammonia removal and transformation by biofiltration, J. Hazard. Mater. 80 (2000) 259-269.

11. G. Busca, C. Pistarino, Abatement of ammonia and amines from waste gases: a summary, J. Loss Prevent. Proc. 16 (2003) 157-163.

12. W.J. Chung, C.S. Jin, T.J. Lee, E.M. Kwon, S.G. Jeong, J.K. Park, M.M. Galera, Development of a Two-Step Biofiltration System for the Control of Odorous Emission from Composting Process of Food Waste, in: IWA (Eds.), Proceedings of the 2nd IWA International Workshop \& Conference on Odour \& Volatile Organic Compounds, Singapore, 14-17 September 2003, pp. 14-17.

13. K.J. Park, M.H. Choi, J.H. Hong, Control of composting odor using biofiltration, Compost Sci. Util. 10 (2002) 356-362.

14. E. Smet, H. Van Langenhove, K. Maes, Abatement of high concentrated ammonia loaded waste gases in compost biofilters, Water Air Soil Poll. 119 (2000) 177-190.

15. U.S. Department of Agriculture and U.S. Composting Council, Test methods for the examination of composting and compost, Edaphos International, Houston, TX, 2001.

16. E. Epstein, The science of composting, Technomic Publishing Co., Lancaster, PENN, 1997, pp. 431-446.

17. J. Peigné, P. Girardin, Environmental impacts of farm-scale composting practices, Wat. Air Soil Poll. 153 (2004) 45-68.

18. S.G. Sommer, P. Dahl, Nutrient and carbon balance during the composting of deep litter, J. Agric. Eng. Res. 74 (1999) 145-153. 
19. L.J. Sikora, MSW compost reduces nitrogen volatilization during dairy manure composting, Compost Sci. Util. 7 (1999) 34-41.

20. J.S. Devinny, M.A. Deshusses, T.S. Webster, Biofiltration for Air Pollution Control, Lewis Publishers, Boca Raton, FL, 1999.

21. T. Hartikainen, J. Ruuskanen, M. Vanhatalo, P. Martikainen, Removal of ammonia from air by a peat biofilter, Environ. Technol. 17 (1996) 45-53.

22. G. Baquerizo, J.P. Maestre, T. Sakuma, M.A. Deshusses, X. Gamisans, D. Gabriel, J. Lafuente. A detailed model of a biofilter for ammonia removal: model parameters analysis and model validation, in: J.S. Devinny (Eds.), Proceedings of the 2004 Conference on biofiltration for air pollution control, Redondo Beach, 19-22 October 2004.

23. S. Kim, M.A. Deshusses, Modeling $\mathrm{H}_{2} \mathrm{~S}$ biotrickling filter, in: J.S. Devinny, F.E. Reynolds (Eds.), Proceedings of the 2002 USC-TRG Conference on Biofiltration, Newport Beach, 31 October - 1 November 2002. 


\section{Tables}

Table 1: Properties of biofilter media before and after the biofiltration period.

\begin{tabular}{lcc}
\hline Parameter & Initial & Final \\
\hline Moisture content $(\% \mathrm{wb})$ & 40.40 & 60.80 \\
\hline Organic matter content $(\% \mathrm{db})$ & 59.69 & 48.57 \\
\hline $\mathrm{pH}$ & 8.70 & 8.98 \\
\hline Electrical conductivity $\left(\mathrm{mS} \cdot \mathrm{cm}^{-1}\right)$ & 3.33 & 3.95 \\
\hline Organic-N $(\% \mathrm{db})$ & 3.46 & 3.28 \\
\hline $\mathrm{NH}_{4}{ }^{+}-\mathrm{N}(\% \mathrm{db})$ & 0.33 & 0.93 \\
\hline $\mathrm{C} / \mathrm{N}$ & 8.72 & 6.40 \\
\hline $\begin{array}{l}\text { Respirometric index }\left(\mathrm{mg} \mathrm{O}_{2} \cdot \mathrm{g} \mathrm{OM}^{-1} \cdot \mathrm{h}^{-}\right. \\
1\end{array}$ & 1.03 & 1.82 \\
\hline
\end{tabular}

wb: wet basis; db: dry basis. 
Table 2: Cumulative ammonia emissions (before and after biofilter), global loading rate, global elimination capacity and the resulting global removal efficiency for the four composted wastes.

\begin{tabular}{|c|c|c|c|c|c|}
\hline & \multicolumn{2}{|c|}{$\begin{array}{l}\text { Cumulative } \mathrm{NH}_{3} \text { emissions } \\
\qquad\left(\mathrm{mg} \mathrm{NH} \mathrm{NH}_{3} \cdot \mathrm{m}^{-3}\right)\end{array}$} & \multirow{2}{*}{$\begin{array}{l}\text { Loading Rate } \\
\quad\left(\mathrm{mg} \mathrm{NH}_{3} \cdot\right. \\
\left.\mathrm{m}^{-3} \text { biofilter } \cdot \mathrm{h}^{-1}\right)\end{array}$} & \multirow{2}{*}{$\begin{array}{c}\text { Elimination } \\
\text { Capacity } \\
\left(\mathrm{mg} \mathrm{NH}_{3} \cdot\right. \\
\left.\mathrm{m}^{-3} \text { biofilter } \cdot \mathrm{h}^{-1}\right)\end{array}$} & \multirow{2}{*}{$\begin{array}{c}\text { Removal } \\
\text { Efficiency } \\
(\%)\end{array}$} \\
\hline & $\begin{array}{l}\text { Before } \\
\text { biofilter }\end{array}$ & $\begin{array}{l}\text { After } \\
\text { biofilter }\end{array}$ & & & \\
\hline OFMSW (5:1) & 773 & 11.3 & 846 & 829 & 98.8 \\
\hline OFMSW (1:1) & 6310 & 289 & 7500 & 7170 & 95.9 \\
\hline DS & 8510 & 89.2 & 6670 & 6580 & 99.4 \\
\hline AP (day 0-4) & 53400 & 4580 & 67100 & 61300 & 89.5 \\
\hline (day 4-9) & 36100 & 15300 & 37500 & 21700 & 46.7 \\
\hline
\end{tabular}




\section{Figure Legends}

Figure 1: Scheme of the pilot scale composting and biofiltration system. 1-Composter; 2-Biofilter; 3-Air inlet; 4-Leachates outlet; 5-Temperature probe; 6-Exhaust gas from composter and inlet biofilter gas; 7-Suction type-blower; 8-Ammonia sensor; 9-Oxygen sensor; 10-Compost media; 11-Sampling ports; 12-Manometer; 13-Outlet biofilter gas; 14-Data logger and control system; 15-Personal computer.

Figure 2: Ammonia emissions in inlet (circles) and outlet (triangles) gas streams of biofilter, average removal efficiency (squares) and temperature (solid line) of composting process of source-selected organic fraction of municipal solid wastes (5:1).

Figure 3: Ammonia emissions in inlet (circles) and outlet (triangles) gas streams of biofilter, average removal efficiency (squares) and temperature (solid line) of composting process of source-selected organic fraction of municipal solid wastes (1:1).

Figure 4: Ammonia emissions in inlet (circles) and outlet (triangles) gas streams of biofilter, average removal efficiency (squares) and temperature (solid line) of composting process of digested wastewater sludge.

Figure 5: Ammonia emissions in inlet (circles) and outlet (triangles) gas streams of biofilter, average removal efficiency (squares) and temperature (solid line) of composting process of animal by-products.

Figure 6: Average elimination capacity of the compost biofilter for different loading rates during composting of source-selected organic fraction of municipal solid wastes, digested wastewater sludge and animal by-products (day 0-4) (circles) and during composting of animal by-products (day 4-9) (triangles). 
Figure 1: Pagans et al.

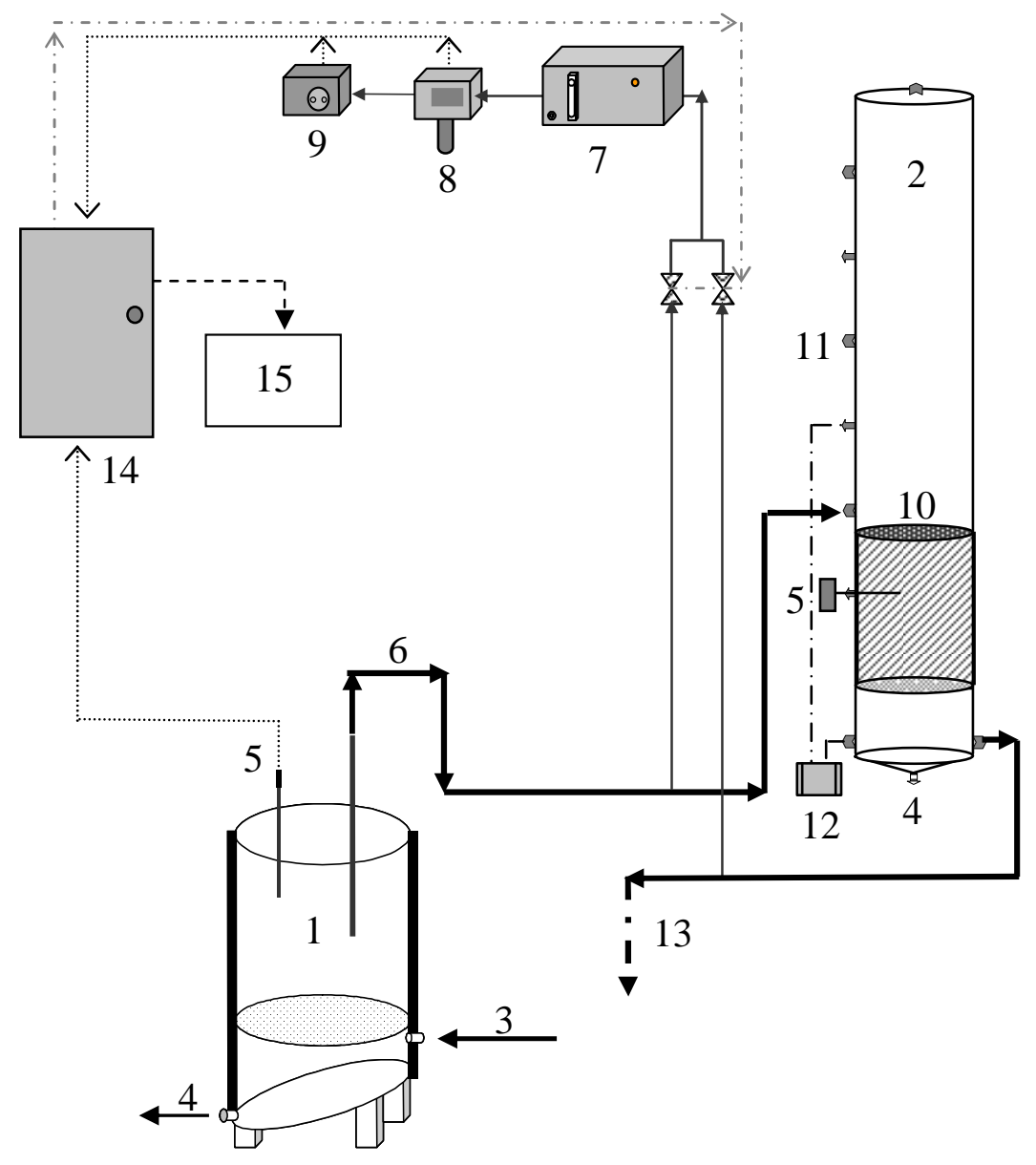


Figure 2: Pagans et al.

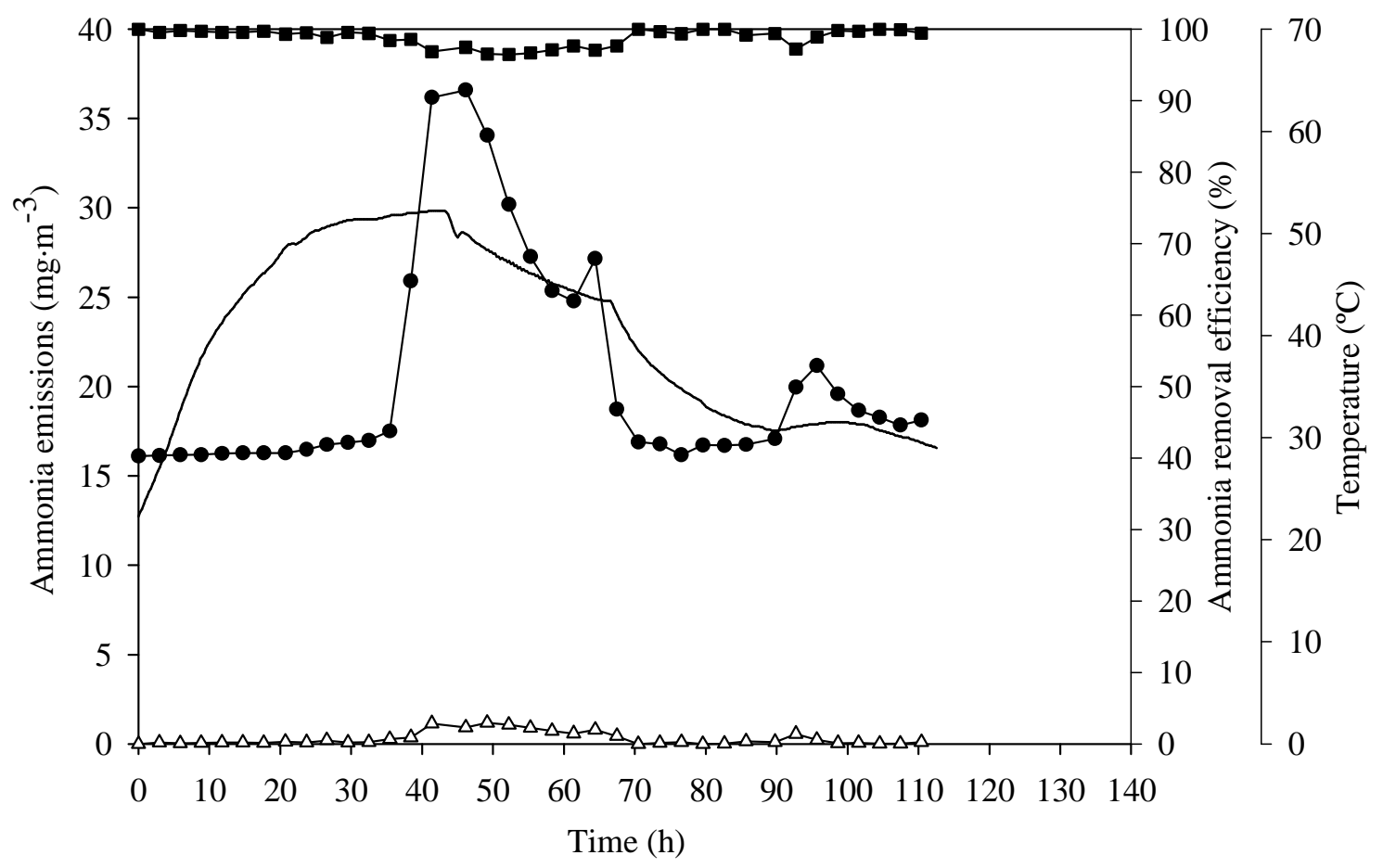


Figure 3: Pagans et al.

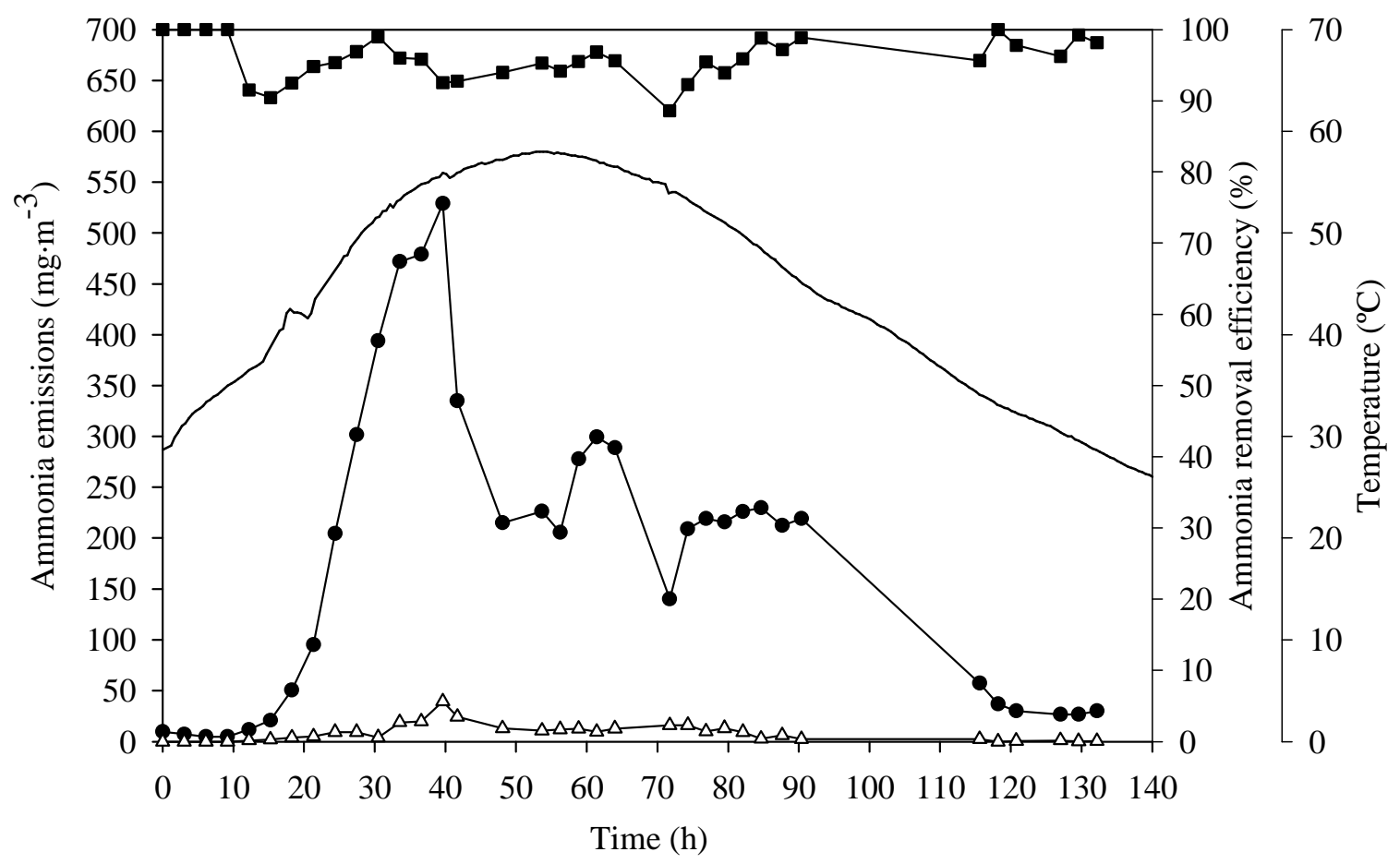


Figure 4: Pagans et al.

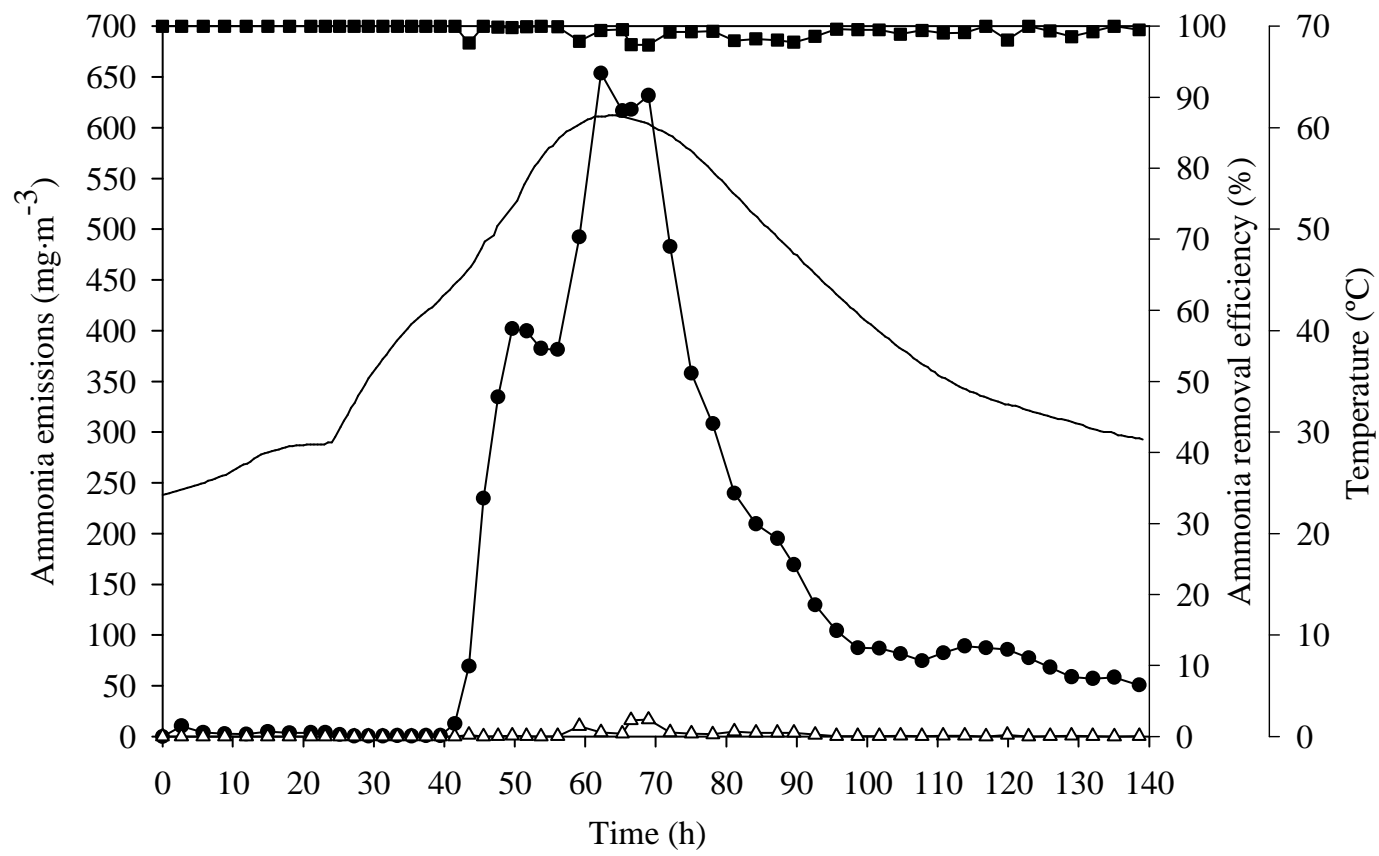


Figure 5: Pagans et al.

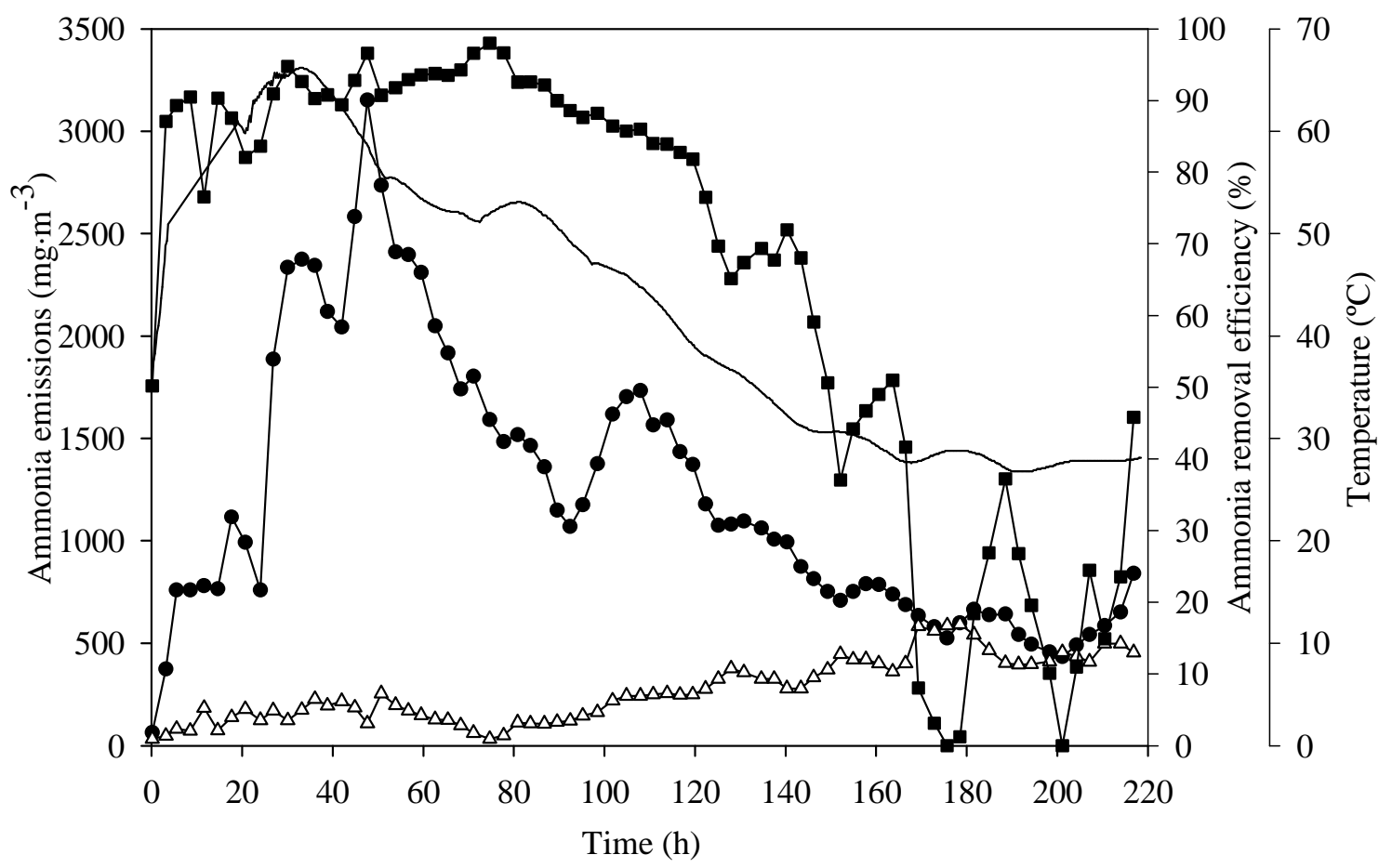


Figure 6: Pagans et al.

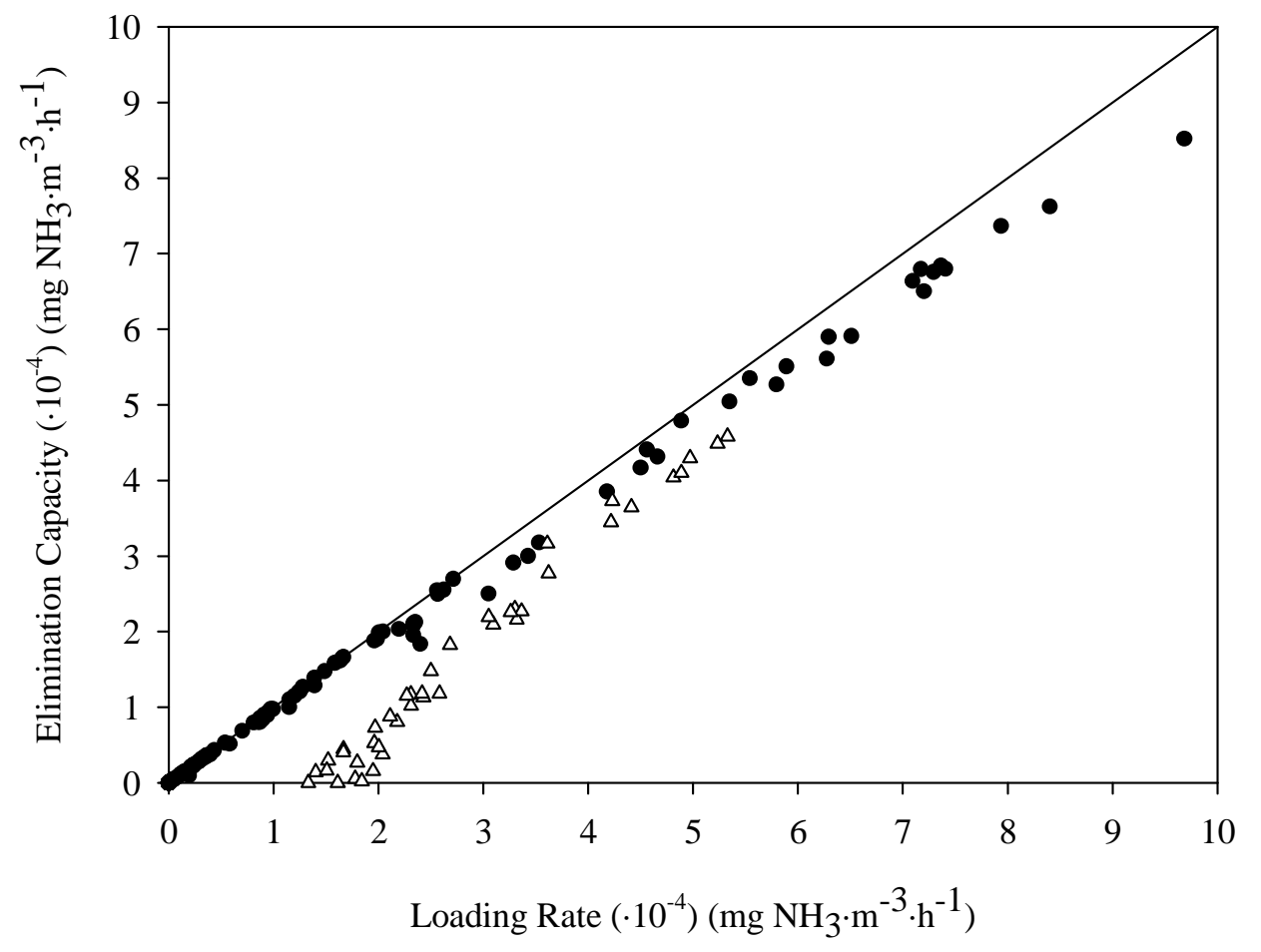

